\title{
PENGEMBANGAN MODEL PERMAINAN ATLETIK ANAK DALAM PEMBELAJARAN GERAK DASAR LARI BAGI SISWA BERKEBUTUHAN KHUSUS (TUNARUNGU) DI SLB NEGERI KABUPATEN KARAWANG
}

\author{
Akhmad Dimyati \\ Universitas Singaperbangsa Karawang \\ Email: akhmad.dimyati@fkip.unsika.ac.id
}

\begin{abstract}
ABSTRAK
Tujuan dari penelitian ini adalah untuk menghasilkan produk permainan atletik nomor lari melalui permainan Atletik Anak untuk siswa SLB. Penelitian ini merupakan penelitian pengembangan. Adapun prosedur pengembangan produk meliputi analisis produk yang akan diciptakan, mengembangkan produk awal, validasi ahli dan revisi, uji coba kelompok kecil dan revisi, uji coba kelompok besar dan produk akhir. Pengumpulan data dilakukan dengan menggunakan kuesioner yang diperoleh dari evaluasi ahli, serta menggunakan hasil pengamatan dilapangan yang diperoleh dari siswa. Teknik analisis data yang digunakan adalah deskriptif persentase. Dari hasil uji ahli diperoleh persentase rata-rata hasil analisis produk sebesar $83,66 \%$ dengan kriteria "baik". Oleh karena itu dapat digunakan. Data hasil pengamatan dan kuisioner siswa pada uji coba skala kecil diperoleh rata- rata dengan persentase $67,96 \%$ dengan kriteria "cukup baik". Data hasil pengamatan dan kuisioner siswa uji coba skala besar diperoleh ratarata dengan persentase $76,45 \%$ dengan kriteria "baik". Pada uji coba kelompok kecil dan uji coba kelompok besar terjadi peningkatan hasil pengamatan dan kuisioner siswa dengan persentase $8 \%$. Dari data yang maka dapat disimpulkan bahwa model permainan atletik anak dalam pembelajaran gerak dasar lari ini dapat digunakan bagi siswa berkebutuhan khusus (tunarungu) SLB Negeri Karawang karena dapat diterima siswa dan menghasilkan produk pembelajaran. Berdasarkan data hasil penelitian, diharapkan bagi guru pada Sekolah Dasar Luar Biasa dapat menggunakan model permainan atletik anak yang sehingga dapat meningkatkan kemampuan atletik nomor lari dengan baik. Produk yang dihasilkan dari penelitian ini dapat digunakan sebagai alternative penyampaian materi pembelajaran atletik nomor lari pada siswa Sekolah Dasar Luar Biasa.
\end{abstract}

Kata Kunci : Pengembangan, Permainan Atletik Anak Berkebutuhan Khusus

\section{ABSTRACK}

The purpose of this research is to produce athletic game products number run through Child Athletics game for SLB students. This research is a development research. The product development procedures include product analysis to be created, initial product development, expert validation and revision, small group trial and revision, large group trials and end products. The data were collected by using questionnaires obtained from expert evaluation, and using field observations obtained from students. Data analysis technique used is descriptive percentage. From the results of expert test obtained the average percentage of product analysis results of $83.66 \%$ with the criteria of "good". It can therefore be used. Student observation data and student questionnaires on small-scale trials were obtained on average with a percentage of $67.96 \%$ with "good enough" criteria. Data on observations and questionnaires of large-scale trial students were obtained on average with a percentage of $76.45 \%$ with "good" criteria. In small group trials and large group trials an increase in 
observations and questionnaires of students with a percentage of $8 \%$. From the data then it can be concluded that the model of athletic games of children in learning the basic motion run can be used for students with special needs (deaf) SLB Negeri Karawang because it can be accepted students and produce learning products. Based on the data of the research results, it is expected for teachers in Primary School Extraordinary can use the model of athletic games of the child so that can improve the ability of athletic number run well. Products produced from this research can be used as an alternative delivery of athletic learning materials running number on elementary school students Extraordinary

Keywords: Development, Athletic Games Children With Special Needs

\section{PENDAHULUAN}

Setelah melakukan observasi awal, kemudian peneliti melakukan wawancara terkait pembelajaran gerak dasar lari pada siswa SLB Negeri Karawang pada tanggal 9 Februari 2017 dengan guru penjasorkes. Pembelajaran gerak dasar lari yang dilakukan guru adalah siswa berlari dengan jarak $40 \mathrm{~m}$ secara bolak-balik dan dihitung waktu tercepat. Pembelajaran yang dilakukan guru tersebut masih monoton belum ada unsur modifikasi dan belum bisa membuat suatu pembelajaran yang efektif, siswa cenderung merasa bosan dan kurang bersemangat dalam mengikuti pembelajaran, sehingga dibutuhkan suatu modifikasi model pembelajaran gerak dasar lari yang lebih menarik yang dapat membuat siswa merasa bersemangat dalam mengikuti pembelajaran. Hal lain yang dapat peneliti ketahui dari wawancara tersebut adalah kesulitan utama dalam mengajar penjasorkes untuk anak tunarungu adalah masalah komunikasi, guru dalam memberikan instruksi dan memberikan elaborasi materi yang dibawakan harus menggunakan bahasa yang sudah dikuasai oleh siswa tunarungu, sehingga tidak menimbulkan salah persepsi oleh siswa. Selain masalah komunikasi, siswa tunarungu juga cenderung lebih sukar diatur. Melihat kelengkapan sarana dan prasarana yang dimiliki SLB N Karawang untuk dapat menunjang pembelajaran penjasorkes sebetulnya sudah terbilang cukup baik, disana terdapat sebuah aula indoor dan sebidang lapangan basket, berbagai jenis bola besar seperti bola basket, bola voli, bola sepak sampai jenis bola kecil seperti bola tenis dan bola bocce juga ada, tongkat estafet dan matras juga tersedia disana. Kelengkapan sarana dan prasarana yang sudah cukup baik tersebut tidak akan berarti apa-apa tanpa kreatifitas dan inovasi seorang guru dalam mengembangkan model pembelajaran yang dapat menarik minat siswa untuk dapat bergerak aktif dan bersemangat dalam mengikuti pelajaran Penjasorkes.

Berdasarkan hasil observasi dan wawancara terhadap pelaksanaan pembelajaran penjasorkes di SLB N Karawang, peneliti dapat mengambil garis besar bahwa dalam kelas tunarungu, pembelajaran Penjasorkes pada pendalaman materi gerak dasar lari belum dikemas secara menarik dan belum dapat mendorong siswa untuk dapat bergerak secara aktif dan bersemangat untuk mengikuti pembelajaran. Pendidikan jasmani untuk penyandang tunarungu hendaknya disesuaikan dan dimodifikasi sedemikian rupa sesuai tingkat kemampuan anak tunarungu, dan dapat diberikan dengan cara berbagai permainan yang menarik sekaligus mudah dipahami dan juga dilaksanakan oleh siswa penyandang tunarungu itu sendiri.

Pendidikan adalah rekonstruksi aneka pengalaman peristiwa yang dialami individu agar segala sesuatu yang baru menjadi lebih terarah dan bermakna. Suherman (2000:1), menyatakan pendidikan mempunyai tujuan utama yaitu mengembangkan 
individu secara menyeluruh baik aspek afektif, kognitif dan psikomotor, dari tujuan utama diatas Pendidikan Jasmani dapat digunakan sebagai sarana menuju pencapaian tujuan utama tersebut.

Undang-undang Republik Indonesia Nomor 2 Tahun 1989 tentang Sistem Pendidikan Nasional atau yang lebih dikenal dengan sebutan Undang-undang Sistem Pendidikan Nasional (UUSPN) pasal 1 ayat 1 dinyatakan bahwa pendidikan adalah usaha sadar untuk menyiapkan peserta didik melalui kegiatan bimbingan, pengajaran, dan/atau latihan dari perannya di masa yang akan dating (Mikarsa dkk, 2009:1.4). Menurut Tilaar dalam Mikarsa dkk (2009:1.4) merumuskan hakikat pendidikan sebagai suatu proses menumbuhkembangkan eksistensi peserta didik yang memasyarakat, membudaya, dalam tata kehidupan yang berdimensi lokal, nasional dan global.

Rumusan hakikat pendidikan tersebut memiliki komponen-komponen sebagai berikut:

1) Pendidikan merupakan proses berkesinambungan. Proses pendidikan mengimplikasikan bahwa peserta didik memiliki kemampuan-kemampuan yang tetap ada sebagai makhluk sosial, dan juga mengimplikasikan bahwa manusia adalah makhluk yang tidak pernah selesai.

2) Proses pendidikan berarti menumbuhkembangkan eksistensi manusia. Artinya bahwa keberadaan manusia adalah suatu keberadaan interaktif. Interaksi manusia ini tidak saja dengan sesamanya, tetapi juga dengan alam, ide, dan dengan Tuhannya.

3) Eksistensi manusia yang memasyarakat. Proses pendidikan adalah proses mewujudkan eksistensi manusia yang memasyarkat.

\section{Pengertian Pendidikan Jasmani}

Pendidikan jasmani adalah suatu proses pembelajaran melalui aktivitas jasmani yang didesain khusus untuk meningkatkan kebugaran jasmani, mengembangkan ketrampilan motorik, pengetahuan dan perilaku hidup sehat dan aktif, sikap sportif, dan kecerdasan emosi. Lingkungan belajar diatur secara saksama untuk meningkatkan pertumbuhan dan perkembangan seluruh ranah jasmani, psikomotor, kognitif, dan afektif setiap siswa, (Samsudin, 2008:2).

\section{Pengertian Penjas Adaptif}

Pendidikan jasmani adaptif merupakan suatu system penyampaian layanan yang bersifat menyeluruh (comprehensive) dan dirancang untuk mengetahui, menemukan dan memecahkan masalah dalam ranah psikomotor.

Menurut Tarigan (2000:8) berkaitan dengan pendidikan jasmani (penjas) adaptif, perlu ditegaskan bahwa siswa yang memiliki kecacatan mempuyai hak yang sama dengan semua yang tidak cacat dalam memperoleh pendidikan dan pembelajaran pada setiap jenjang pendidikan. Para siswa yang cacat, sesuai dengan kecacatanya akan memperoleh pembinaan melalui pendidikan jasmani yang menjadi tugas utama para guru penjas yang telah mendapatkan mata kuliah penjas adaptif.

Menurut Hendrayana (2007:6) pendidikan jasmani adaptif adalah sebuah program yang bersifat individual yang meliputi fisik/jasmani, kebugaran gerak, pola dan ketrampilan gerak dasar, keterampilan-keterampilan dalam aktivitas air, menari, permainan olahraga baik individu maupun beregu yang didesain bagi penyandang cacat. 


\section{Pengertian Anak Berkebutuhan Khusus}

Anak berkebutuhan khusus bersifat sementara (temporer) adalah anak yang mengalami hambatan belajar dan hambatan perkembangan faktor-faktor eksternal, misalnya : anak yang mengalami gangguan emosi karena trauma akibat kecelakaan sehingga anak ini tidak dapat belajar.

\section{Strategi Pembelajaran PAIKEM}

Pemilihan strategi pembelajaran harus didasarkan pada situasi, kondisi, lingkungan yang dihadapi maka dari itu strategi pembelajaran PAIKEM adalah satu strategi yang dapat diterapkan. PAIKEM merupakan sinonim dari pembelajaran aktif, inovatif, kreatif, efektif, menarik, (Uno dan Mohamad, 2012:10).

\section{Pengertian Lari}

Pengertian lari dikutip dari Khomsin dalam Widodo (2008:11) mengatakan bahwa lari adalah gerakan berpindah tempat atau bergerak maju ke depan yang dilakukan dengan cepat, karena adanya gaya dorong kaki belakang pada tanah yang dilakukan dengan mengais, sehingga kedua kaki dapat melayang di udara pada saat berlari. Perbedaan utama pada jalan dan lari adalah sebagai berikut. Pada jalan, salah satu kaki harus tetap ada yang kontak dengan tanah (support phase), sedangkan pada lari, kedua kaki ada saat melayang di udara (kedua telapak kaki lepas dari tanah). (Bahagia, dkk, 2000:11).

\section{METODE PENELITIAN}

\section{Metode}

Penelitian ini merupakan penelitian pengembangan yang bertujuan menghasilkan produk model pembelajaran gerak dasar melalui permainan atletik anak bagi siswa tunarungu Sekolah Dasar Luar Biasa (SLB). Menurut Borg dan Gall dalam menyatakan bahwa, penelitian dan pengembangan merupakan metode penelitian yang digunakan untuk mengembangkan atau memvalidasi produk-produk yang digunakan dalam pendidikan dan pembelajaran.

Langkah yang digunakan dalam penelitian ini adalah :

1. Melakukan penelitian pendahuluan dan pengumpulan informasi, dilakukan dengan cara observasi lapangan dan kajian pustaka.

2. Mengembangkan produk awal (berupa peraturan permainan atletik anak dan cara bermain).

3. Evaluasi ahli dengan menggunakan satu Dosen (Ahli Penjas Adaptif) dan dua Guru Penjas SLB, serta uji coba kelompok kecil dengan menggunakan kuisioner, konsultasi, serta evaluasi yang kemudian akan dianalisis.

4. Revisi produk awal, revisi produk awal dilakukan berdasarkan hasil evaluasi yang diberikan oleh dosen (ahli penjas adaptif) dan guru penjas SLB serta hasil dari uji coba kelompok kecil, revisi bertujuan untuk perbaikan dan penyempurnaan produk awal yang telah dibuat.

5. Uji coba lapangan atau uji skala besar, dilakukan dengan menggunakan model produk yang sudah direvisi berdasarkan uji coba skala kecil.

6. Revisi produk, revisi produk ini dilakukan berdasarkan uji coba skala besar dan akan menyempurnakan produk akhir.

7. Hasil akhir model pembelajaran pengembangan gerak dasar melalui permainan atletik anak bagi siswa tunarungu di SLB Negeri Karawang yang dihasilkan dari 
revisi uji lapangan.

Populasi dalam penelitian ini yaitu seluruh siswa di SLB Negeri Kabupaten Karawang yang berjumlah 65 siswa, sedangkan sampelnya sebanyak 20 siswa menggunakan teknik penarikan sampel purposive sampling, dikarenakan hanya ada sekian siswa tunarungu di SLB Negeri Kabupaten Karawang.

\section{A. Analisis Kebutuhan}

Analisis kebutuhan merupakan langkah awal dalam penelitian ini. Langkah ini bertujuan untuk menentukan apakah model pembelajaran pengembangan gerak dasar melalui permainan atletik anak ini dibutuhkan atau tidak. Dalam tahap ini peneliti melakukan observasi lapangan di SLB Negeri Karawang tentang pelaksanaan pembelajaran yang berlangsung untuk siswa tunarungu di tingkat SLB.

\section{B. Pembuatan Produk Awal}

Berdasarkan hasil observasi yang telah dilakukan, maka langkah selanjutnya adalah pembuatan produk model permainan atletik anak. Dalam pembuatan produk yang dikembangkan, peneliti membuat produk berdasarkan kajian teori yang kemudian di evaluasi oleh satu dosen ahli penjas adaptif dan dua guru penjas SLB. Subjek dari penelitian ini adalah siswa tunarungu SLB Negeri Karawang.

\section{Uji Coba Produk}

Pelaksanaan uji coba produk dilaksanakan melalui beberapa tahap yaitu: (1) menetapkan desain uji coba, (2) menentukan subjek uji coba, (3) menyusun instrumen pengumpulan data, dan (4) menetapkan teknik analisis data.

\section{Revisi Produk Awal}

Setelah melewati uji coba produk, maka akan dilakukan revisi produk awal hasil dari evaluasi ahli dan uji coba skala kecil sebagai perbaikan produk awal yang telahdiujicobakan.

\section{E. Uji Coba Lapangan}

Uji coba lapangan tahap ini memuat kegiatan uji coba lapangan terhadap produk yang dikembangkan dengan menggunakan subjek uji coba siswa tunarungu SLB Negeri Semarang Kota Semarang yang berjumlah 20 orang.

\section{F. Revisi Produk Akhir}

Revisi produk dari hasil uji lapangan yang telah dilakukan uji coba kepada siswa tunarungu SLB Negeri Semarang Kota Semarang yang berjumlah 20 orang.

\section{G. Hasil Akhir}

Hasil akhir produk pengembangan dari uji lapangan yang berupa model pembelajaran pengembangan gerak dasar melalui permainan atletik anak.

\section{Uji Coba Produk}

Uji coba produk penelitian bertujuan untuk memperoleh kesesuaian, efektifitas, dan kebermanfaatan dari produk. Langkah yang dilaksanakan dalam pelaksanaan uji coba produk ini adalah sebagai berikut :

\section{A. Desain Uji Coba}

Desain uji coba yang dilaksanakan bertujuan untuk mengetahui tingkat kesesuaian, keefektifan, dan manfaat produk yang dikembangkan. Desain uji coba yang dilaksanakan terdiri dari sebagai berikut :

\section{a) Evaluasi Ahli}


Sebelum dilakukan uji coba kepada subjek tehadap produk permainan pembelajaran, produk yang telah dibuat dievaluasi terlebih dahulu oleh satu ahli penjas adaptif Teten Hidayat, M.Pd. dan dua guru penjas SLB. Variabel yang dievaluasi oleh ahli meliputi peraturan permainan, cara mengawali permainan, jumlah pemain, serta fasilitas dan peralatan. Untuk menghimpun data dari para ahli dilakukan dengan cara memberikan draf awal model dengan disertai lembar evaluasi kepada para ahli. Hasil evaluasi ahli tersebut yang berupa penilaian dan saran terhadap produk awal yang sudah dibuat, akan digunakan sebagai dasar pedoman pengembangan produk selanjutnya.

\section{b) Uji Coba Kelompok Kecil}

Tahapan ini berisi tentang uji coba produk yang telah direvisi oleh para ahli. Hasil revisi tersebut kemudian diujicobakan kepada siswa tunarungu SLB Negeri Semarang. Pada uji coba kelompok kecil ini menggunakan 20 siswa tunarungu sebagai subjeknya. Pengambilan 20 anak tunarungu sebagai subjek dilakukan dengan cara acak (simple random sampling).

Sebelum melakukan uji coba kelompok kecil awalnya siswa diberi penjelasan mengenai permainan atletik anak, setelah itu baru dilakukan uji coba permainan, setelah selesai melakukan uji coba siswa melakukan pengisian kuesioner mengenai permainan yang telah dilakukan. Tujuan dari uji coba adalah untuk mengetahui tanggapan awal dari produk yang akan dikembangkan ke depannya.

\section{Uji Coba Lapangan}

Hasil analisis uji coba kelompok kecil serta revisi produk awal, selanjutnya dilakukan uji coba lapangan yang akan dilakukan dengan subjek 65 siswa tunarungu SLB Negeri Semarang Kota Semarang. Seperti pada uji coba kelompok kecil siswa kembali diberikan penjelasan mengenai permainan atletik anak. Setelah selesai kemudian siswa melakukan permainan atletik anak kemudian siswa mengisi kuesioner mengenai permainan yang baru saja dilakukan.

\section{Subjek Uji Coba}

Subjek yang digunakan dalam uji coba penelitian ini adalah sebagai berikut:

1. Evaluasi ahli yang terdiri dari satu ahli penjas adaptif dan dua guru penjas SLB.

2. Uji coba kelompok kecil yang terdiri dari 20 siswa tunarungu SLB Negeri Karawang dipilih menggunakan sampel secara acak (simple random sampling).

3. Uji coba lapangan dilakukan oleh 65 siswa tunarungu SLB Negeri Karawang sample dipilih secara acak (simple random sampling).

\section{HASIL PENELITIAN DAN PEMBAHASAN}

\section{Validasi Draf Produk Awal}

Produk awal pengembangan permainan Formula 1 (Run, Jump, Throw) untuk pembelajaran atletik anak untuk peserta didik SLB (TUNARUNGU), sebelum uji coba skala kecil perlu divalidasi oleh para ahli yang sesuai dengan bidang penelitian ini. Untuk memvalidasi produk yang akan dihasilkan, peneliti melibatkan 1 (satu) orang ahli Penjas yang berasal dari guru penjasorkes dan 2 (dua) orang ahli pembelajaran yang juga berasal dari guru penjasorkes.

Satu ahli Penjas yaitu Daimah, S.Pd dan dua ahli pembelajaran yaitu Sukir, S.Pd, Fatchurrachman dengan kualifikasi: (1) Daimah, S.Pd adalah guru penjasorkes di SLBN Karawang, (2) Sukir, S.Pd adalah guru penjasorkes di SLB (TUNARUNGU) Negeri Karawang (3) Fatchurrachman adalah guru Penjasorkes di SLB 
(TUNARUNGU) Negeri Karawang.

Validasi dilakukan dengan cara memberikan draf produk awal permainan Formula 1 (Run, Jump, Throw) dengan disertai lembar evaluasi untuk ahli Penjas dan ahli pembelajaran. Lembar evaluasi berupa kuesioner yang berisi aspek kualitas model permainan, saran, serta komentar dari ahli Penjas dan ahli pembelajaran terhadap produk permainan Formula 1 (Run, Jump, Throw) sebagai media pembelajaran atletik anak umtuk peserta didik SLB (TUNARUNGU). Hasil evaluasi berupa nilai dari aspek kualitas model pembelajaran dengan menggunakan skala 1 sampai 5. Lembar evaluasi atau kuesioner untuk kualitas produk permainan Formula 1 (Run, Jump, Throw), dapat dilihat pada lampiran 6 halaman.

\section{Deskripsi Data Validasi Ahli}

Data yang sudah diperoleh dari pengisian lembar evaluasi oleh para ahli, yaitu satu ahli penjas dan dua ahli pembelajaran, merupakan pedoman untuk menyatakan apakah produk model pengembangan permainan Formula 1 (Run, Jump, Throw) ini dapat digunakan untuk melakukan penelitian uji coba skala kecil dan uji coba lapangan/uji coba skala besar. Berikut ini adalah hasil pengisian lembar evaluasi dari ahli Penjas dan ahli pembelajaran.

Tabel 1. Hasil Rata-Rata Skor Penilaian Ahli

\begin{tabular}{ccc}
\hline No & Ahli & Hasil Prosentase Skor Penilaian \\
\hline 1 & Ahli Penjas & $92 \%$ \\
\hline 2 & Ahli Pembelajaran I & $93 \%$ \\
\hline 3 & Ahli Pembelajaran II & $96 \%$ \\
\hline
\end{tabular}

Berdasarkan hasil pengisian kuesioner yang dilakukan oleh ahli Penjas dan ahli pembelajaran didapatkan rata-rata lebih dari 4 (empat) atau masuk dalam kategori penilaian "sangat baik". Oleh karena itu, dapat disimpulkan bahwa model permainan Formula 1 (Run, Jump, Throw) bagi siswa kelas IV SLB (TUNARUNGU)) dapat digunakan untuk uji coba skala kecil.

\section{KESIMPULAN}

Berdasarkan hasil penelitian dan pembahasan yang telah diuraikan dalam bab sebelumnya, penulis dapat menarik kesimpulan yaitu: proses pembelajaran pendidikan jasmani anak tunarungu di SLB Negeri Kabupaten Karawang berada pada kategori sedang. Baik dari tujuan pendidikan jasmani, materi pendidikan jasmani adaptif, sikap dan motivasi siswa dalam pendidikan jasmani, kompetensi guru, sarana dan prasarana, dan evaluasi penididikan jasmani masih terlaksana kurang baik.

\section{DAFTAR PUSTAKA}

Bahagia, Yoyo. 2000. Mengajar dan Melatih Atletik. Bandung: Remaja Rosdakarya.

Khomsin dalam Agus Widodo 2013. Strategi Pembelajaran. Bandung: Remaja Rosdakarya 
Suherman, Adang. 2000. Dasar-dasar Penjaskes. Jakarta : Depdikbud.

Mikarsa, Lesmana Hera dkk : 2009. Pendidikan Anak Berkebutuhan Khusus. Jakarta:

Syamsudin. 1992 ATLETIK. Jakarta: Depdikbud.

Ma'mun, Amung dan Saputra, Yudha M. 2000. Perkembangan Gerak dan Belajar Gerak, Jakarta: Depdiknas

Tarigan, Baltasar. 2000. Pendidikan Jasmani Adaptif. Jakarta: Departemen Pendidikan Nasional Dasar dan Menengah.

Uno, Hamzah B. dan Mohamd, Nurdin. 2012. Belajar dengan Pendekatan PAILKEM. Jakarta: Bumi Aksara.

Hendrayana, Yudi. 2007. Penjas Adaptif. Bandung: UPI. 